\title{
Duration of Infectious Virus Shedding in Patients With Severe Coronavirus Disease 2019 Who Required Mechanical Ventilation
}

\section{Toshihito Nomura ( $\nabla$ tnomu@hiroshima-u.ac.jp )}

Hiroshima University Hospital

Hiroki Kitagawa

Hiroshima University Hospital

Keitaro Omori

Hiroshima University Hospital

Norifumi Shigemoto

Hiroshima University Hospital

Masaki Kakimoto

Hiroshima University Hospital

Tanuza Nazmul

Hiroshima University

Nobuaki Shime

Hiroshima University

Takemasa Sakaguchi

Hiroshima University

Hiroki Ohge

Hiroshima University Hospital

\section{Research Article}

Keywords: coronavirus disease (COVID-19), infectious virus shedding, RT-qPCR

Posted Date: April 15th, 2021

DOl: https://doi.org/10.21203/rs.3.rs-395009/v1

License: (c) (1) This work is licensed under a Creative Commons Attribution 4.0 International License.

Read Full License

Version of Record: A version of this preprint was published at Journal of Infection and Chemotherapy on September 1st, 2021. See the published version at https://doi.org/10.1016/j.jiac.2021.09.006. 


\section{Abstract}

Approximately $5 \%$ of patients with coronavirus disease (COVID-19) caused by severe acute respiratory syndrome coronavirus 2 develop severe COVID-19. Severe COVID-19 requires respiratory management with mechanical ventilation and an extended period of treatment. Prolonged infectious virus shedding is a concern in severe COVID-19 cases, but few reports have examined the duration of infectious virus shedding. Therefore, we investigated the duration of infectious virus shedding in patients transferred to Hiroshima University Hospital with severe COVID-19 requiring mechanical ventilation.

Nasopharyngeal swab specimens were collected and analyzed using both viral culture and reverse transcriptase-quantitative polymerase chain reaction (RT-qPCR) tests between December 2020 and February 2021.

Of the 23 patients tested, the proportions of those with positive test results at first specimen collection on RT-qPCR and viral culture tests were $95.7 \%$ and $30 \cdot 4 \%$, respectively. All six patients with positive viral culture test results who were followed-up tested negative 24 days after symptom onset but remained positive on RT-qPCR. The longest negative conversion time was observed in a dialysis patient on immunosuppressive drugs.

This study indicated that patients with severe COVID-19 remain culture positive for $\geq 10$ days after symptom onset. Additionally, immunosuppressed patients with severe COVID-19 could consider isolation for $\geq 20$ days.

\section{Introduction}

Cases of coronavirus disease (COVID-19) caused by severe acute respiratory syndrome coronavirus 2 (SARS-CoV-2) continue to increase worldwide. Approximately $5 \%$ of patients with COVID-19 develop severe COVID-19 and require mechanical ventilation ${ }^{1}$. Numerous reports have shown that viral culture test results become negative 10 days after symptom onset ${ }^{2-4}$. In mild cases, from day 10 onwards, isolation is recommended for $24 \mathrm{~h}$ after the disappearance of symptoms such as fever. In contrast, severe cases are believed to exhibit prolonged infectious virus shedding, and isolation for about 20 days is recommended by the Centers for Disease Control and Prevention (CDC) and the European Centre for Disease Prevention and Control ${ }^{5,6}$. Nevertheless, an insufficient number of reports have examined the duration of infectious virus shedding in severe cases, and determining when to end isolation remains a major concern for medical institutions treating patients with severe COVID-19. A positive virus culture test result has been reported from a specimen collected 20 days after symptom onset ${ }^{7}$. A positive viral culture test result has even been reported on around day 70 after symptom onset in a patient with T-cell deficiency ${ }^{8}$.

We assessed the duration of virus shedding in patients with severe COVID-19 by performing viral culture and reverse transcriptase-quantitative polymerase chain reaction (RT-qPCR) testing of patients with 
severe COVID-19 who required mechanical ventilation and were admitted to Hiroshima University Hospital for treatment.

\section{Methods}

Study participants and procedure

The study included 23 patients with severe COVID-19 who required mechanical ventilation and were admitted to Hiroshima University Hospital for treatment between December 2, 2020 and February 5, 2021. Hiroshima University Hospital accepts hospital transfers of patients with severe COVID-19 who require intubation management in Hiroshima Prefecture and provides treatment in its intensive care unit.

Nasopharyngeal swab specimens were collected with a swab and $1 \mathrm{~mL}$ of physiological saline. The first specimen was collected within one to two days after transfer to Hiroshima University Hospital. When the first viral culture test result was positive and circumstances allowed for follow-up, the duration of infectious virus shedding was investigated by collecting specimens every three to four days until negative viral culture conversion was observed. Patient information (date of symptom onset, medical history, medications, body mass index [BMI]) was extracted from the hospital's electronic medical records. Medical history of patients was only included in this study when there was evidence of a link between having a medical history and the occurrence of severe COVID-199.

Cell and viral culture

SARS-CoV-2 was cultured in Vero cells expressing TMRPSS2 (VeroE6/TMRPSS2 cells, procured from JCRB cell bank, Japan). Cultures were observed for seven days and checked for cytopathic effects (CPEs). Infectivity titer was measured based on $50 \%$ tissue culture infectious dose $\left(\mathrm{TCID}_{50}\right)$, while $\mathrm{TCID}_{50} / \mathrm{mL}$ was calculated using a method described in a previous report ${ }^{10}$. When no CPEs were observed within seven days, the culture was considered negative.

RT-qPCR

RT-qPCR tests were performed using a method described in a previous report ${ }^{10}$. SARS-CoV-2 nucleic acids were extracted using a Viral Total Nucleic Acid Purification Kit (Promega Corporation, USA), while RTqPCR was performed using a One Step PrimeScript ${ }^{\text {TM }}$ III RT-qPCR mix (Takara Bio Inc., Japan). N genes were targeted using the forward primer $(2.4 \mu \mathrm{M}), 5^{\prime}$-AAA TTT TGG GGA CCA GGA AC-3', reverse primer (3.2 $\mu \mathrm{M}), 5$ '-TGG CAG CTG TGT AGG TCA AC-3', and probe $(0.4 \mu \mathrm{M})$ 5'-FAM-ATG TCG CGC ATT GGC ATG GABHQ-3'. RT-qPCR was run according to the manufacturer's protocol. A known quantity of SARS-CoV-2 RNA was used as a positive control, and copies $/ \mathrm{mL}$ were calculated from cycle threshold (Ct) values.

Ethics 
All methods were performed in accordance with the relevant guidelines and regulations. This research was approved by the Ethical Committee for Epidemiology of Hiroshima University (approval number: E2157). The requirement for written informed consent was waived because only the patients' clinical specimens were used in this study, and the patients had the right to opt-out from the use of their surplus patient material and medical data for research.

\section{Statistical analysis}

Fisher's exact test and the Mann Whitney U test were used to compare patient characteristics. Statistical significance was set at $p<0.05$. Statistical analysis was performed using JMP software version 15 (SAS Institute Inc., USA).

\section{Results}

\section{Patient characteristics}

Thirty-three nasopharyngeal swab specimens were collected from 23 patients. Characteristics of patients included in the study are shown in Table 1. Patients were categorized into culture-positive (seven patients, $30 \cdot 4 \%$ ) and culture-negative (16 patients, $69 \cdot 6 \%$ ) groups, depending on initial viral culture test results. The median number of days prior to the first specimen collection was 10 days after symptom onset (culturepositive group: nine days, culture-negative group: 10 days; $p=0.2358$ ). The median patient age was 64.0 years (culture-positive group: 67.0 years, culture-negative group: 62.5 years; $p=0.6637$ ), and $82.6 \%$ of the patients were men (culture-positive group: $66.7 \%$, culture-negative group: $87.5 \% ; p=0.3518$ ). The median BMI was $28.4 \mathrm{~kg} / \mathrm{m}^{2}$ (culture-positive group: $26.4 \mathrm{~kg} / \mathrm{m}^{2}$, culture-negative group: $30.8 \mathrm{~kg} / \mathrm{m}^{2} ; \mathrm{p}=0.2291$ ), the most frequent comorbidity was hypertension (culture-positive group: $57 \cdot 1 \%$, culture-negative group: $50 \cdot 0 \% ; p=0.5555$ ), and $30 \cdot 4 \%$ of patients had diabetes mellitus (culture-positive group: $14 \cdot 3 \%$, culturenegative group: $37.5 \% ; p=0.2753$ ). No significant difference between the two groups was found in any characteristic. 
Table 1

Patient Characteristics

\begin{tabular}{|c|c|c|c|c|c|c|}
\hline $\begin{array}{l}\text { Patient } \\
\text { No. }\end{array}$ & $\begin{array}{l}\text { Age } \\
\text { (years) }\end{array}$ & Sex & $\begin{array}{l}\text { First } \\
\text { specimen } \\
\text { collection } \\
\text { (days after } \\
\text { symptom } \\
\text { onset) }\end{array}$ & $\begin{array}{l}\text { Negative } \\
\text { culture test } \\
\text { (days after } \\
\text { symptom } \\
\text { onset) }\end{array}$ & $\begin{array}{l}\text { BMI } \\
\left(\mathrm{kg} / \mathrm{m}^{2}\right)\end{array}$ & Medical history \\
\hline \multicolumn{7}{|c|}{ Culture-positive group $(\mathrm{N}=7)$} \\
\hline P3 & 61 & Male & 12 & 24 & 20.3 & $\begin{array}{l}\text { Rheumatoid arthritis } \\
\text { (receiving prednisolone and } \\
\text { abatacept), end-stage renal } \\
\text { failure (undergoing } \\
\text { dialysis), autoimmune } \\
\text { leukopenia }\end{array}$ \\
\hline P7 & 48 & Male & 9 & 16 & 28.4 & Fatty liver \\
\hline P8 & 52 & Male & 10 & N.D & 32.4 & $\begin{array}{l}\text { Diabetes mellitus HbA1C: } \\
11 \cdot 2\end{array}$ \\
\hline P11 & 70 & Male & 9 & 13 & 26.4 & Hypertension \\
\hline P12 & 67 & Male & 10 & 13 & 25.7 & Hypertension \\
\hline P14 & 73 & Female & 8 & 15 & 24.5 & Hypertension \\
\hline P22 & 68 & Female & 4 & 11 & 27.9 & $\begin{array}{l}\text { Rheumatoid arthritis } \\
\text { (receiving Janus kinase } \\
\text { inhibitor and prednisolone), } \\
\text { hypertension }\end{array}$ \\
\hline \multicolumn{7}{|c|}{ Culture-negative group $(\mathrm{N}=16)$} \\
\hline P1 & 53 & Male & 14 & 14 & 23.8 & $\begin{array}{l}\text { Diabetes mellitus HbA1C: } \\
\text { 7.6, interstitial pneumonitis }\end{array}$ \\
\hline P2 & 42 & Male & 11 & 11 & 34.7 & - \\
\hline P4 & 50 & Male & 11 & 11 & 40.7 & $\begin{array}{l}\text { Diabetes mellitus HbA1C: } \\
9.8\end{array}$ \\
\hline P5 & 66 & Male & 9 & 9 & 31.0 & $\begin{array}{l}\text { Diabetes mellitus HbA1C: } \\
8.7\end{array}$ \\
\hline P6 & 72 & Male & 10 & 10 & 29.7 & $\begin{array}{l}\text { Diabetes mellitus HbA1C: } \\
11.9 \text {, hypertension }\end{array}$ \\
\hline P9 & 68 & Male & 9 & 9 & 30.9 & $\begin{array}{l}\text { Diabetes mellitus HbA1C: } \\
7.2 \text {, hypertension }\end{array}$ \\
\hline P10 & 65 & Male & 8 & 8 & 26.1 & Chronic hepatitis C \\
\hline
\end{tabular}

BMI, body mass index; HbA1C, glycated hemoglobin; P, patient; N.D, no data 


\begin{tabular}{|lllllll|}
\hline $\begin{array}{l}\text { Patient } \\
\text { No. }\end{array}$ & $\begin{array}{l}\text { Age } \\
\text { (years) }\end{array}$ & Sex & $\begin{array}{l}\text { First } \\
\text { specimen } \\
\text { collection } \\
\text { (days after } \\
\text { symptom } \\
\text { onset) }\end{array}$ & $\begin{array}{l}\text { Negative } \\
\text { culture test } \\
\text { (days after } \\
\text { symptom } \\
\text { onset) }\end{array}$ & $\begin{array}{l}\text { BMI } \\
\left(\mathbf{k g} / \mathbf{m}^{2}\right)\end{array}$ & Medical history \\
\hline P13 & 57 & Male & 12 & 12 & 23.5 & Hypertension \\
\hline P15 & 81 & Male & 12 & 12 & 24.6 & Hypertension \\
\hline P16 & 77 & Female & 9 & 9 & 33.2 & $\begin{array}{l}\text { Diabetes mellitus HbA1C: } \\
\text { 7.4 }\end{array}$ \\
\hline P17 & 68 & Male & 10 & 10 & 31.7 & Hypertension \\
\hline P18 & 64 & Male & 12 & 12 & 22.3 & Emphysema, hypertension \\
\hline P19 & 59 & Male & 6 & 6 & 23.7 & Hypertension \\
\hline P20 & 54 & Male & 10 & 10 & 30.7 & Hypertension \\
\hline P21 & 29 & Male & 13 & 13 & 36.4 & Crohn's disease \\
\hline P23 & 61 & Female & 8 & 8 & 32.6 & $\begin{array}{l}\text { Rheumatoid arthritis } \\
\text { (receiving methotrexate) }\end{array}$ \\
\hline BM1, body mass index; HbA1C, glycated hemoglobin; P, patient; N.D, no data
\end{tabular}

Test results by specimen

At first specimen collection, $95 \cdot 7 \%$ of the 23 patients tested positive via RT-qPCR results, and $30 \cdot 4 \%$ of the patients tested positive via viral culture. Of the 33 specimens tested, the proportion of those with positive viral culture test results was $33 \cdot 3 \%$. The longest time to produce a positive viral culture test result was 21 days after symptom onset, and the infectivity titer ranged from $1.1 \times 10^{2}$ to $3.6 \times 10^{6} \mathrm{TCID}_{50} / \mathrm{mL}$. Of the 33 specimens considered, the proportion of those with a positive RT-qPCR test result was $97 \cdot 0 \%$ and detected viral loads ranged from $1.3 \times 10^{3}$ to $2.1 \times 10^{9}$ copies/mL (Fig. 1). RT-qPCR test results showed no change in viral load over time, but viral culture test results showed a decrease in infectivity titer over time.

Of the seven patients with an initial positive viral culture test result, specimens were collected and viral culture and RT-qPCR testing were performed in six patients until negative viral culture conversion occurred (Fig. 2). Viral culture testing revealed that the infectivity titer decreased over time and negative viral culture conversion occurred in all six patients (median negative conversion time: 14 days). PCR testing revealed viral loads of at least $10^{4}$ copies $/ \mathrm{mL}$, even in specimens with a negative viral culture test result. One of the seven patients, whose negative viral culture conversion time was 24 days, had been receiving prednisolone and abatacept for rheumatoid arthritis, undergoing dialysis, and had underlying autoimmune leukopenia. 


\section{Discussion}

In patients with severe COVID-19 requiring mechanical ventilation, a large difference in the percentage of positive results between viral culture and PCR testing was revealed. Viral culture testing revealed that viral load decreased over time, while decreases were not observed via PCR testing. Previous reports have also shown that PCR test results remain positive for an extended period, up to 40 days or more in some cases $^{11,12}$. The CDC does not recommend ending isolation based on PCR testing ${ }^{5}$. The results of this study also showed that it is difficult to evaluate whether a patient is infectious based on PCR testing, even if the viral load is known.

In terms of infectivity titers, we confirmed that both the viral load and percentage of positive results decreased over time. One patient required 24 days for negative viral culture conversion to occur. In this patient, factors associated with immunosuppression, including treatment with prednisolone and abatacept, and dialysis for renal failure likely influenced the results. The likelihood that these factors caused severe COVID-19 has already been identified. Previous studies revealed that a high proportion of patients receiving prednisolone for rheumatism developed severe COVID-19 ${ }^{13}$, and the mortality rate of COVID-19 is reportedly higher in patients who are on dialysis than in their counterparts ${ }^{14}$. Nevertheless, the possibility that these factors may lead to viral culture test positivity for prolonged periods has not been fully examined. Though this affected only one patient in this study, the finding suggests that these factors may prolong the negative viral culture conversion time.

For all the other patients in this study, there was no difference in age, BMI, or medical history between the culture-positive and culture-negative groups, and negative viral culture conversion occurred between days 6 and 16 after symptom onset. Furthermore, in this study, approximately one third (30.4\%) of all patients with severe COVID-19 were believed to have been shedding the infectious virus 10 days after symptom onset.

This study has a few limitations. This was a single-center study of a group with a small sample size, and only seven patients had positive viral culture test results. Patients were transferred to our hospital when they required mechanical ventilation and the timing of the first specimen collection was different for each patient. A few specimens were collected within seven days after symptom onset, and we could not investigate the percentage of positive viral culture test results obtained prior to initiating therapy. SARSCoV-2 infectivity was assessed with a viral culture test that used Vero cells expressing TMPRSS2. Vero cells are well suited for SARS-CoV-2 culture ${ }^{15}$, and Vero cells expressing TMPRSS2 are even more susceptible to SARS-CoV-2 infection ${ }^{16}$. However, additional knowledge is required to investigate what factors inhibit viral culture and the detection limits of viral culture.

This study showed that $30 \%$ of the critically-ill patients remained culture positive for $\geq 10$ days after symptom onset. Further, one immunosuppressed patient required 24 days of testing before negative viral culture conversion occurred, suggesting that a longer period of isolation is required for patients with 
impaired cellular immunity. Further research investigating patients with COVID-19 who exhibit prolonged infectious virus shedding is required.

\section{Declarations}

\section{Acknowledgments}

None.

\section{Author Contributors}

This study was designed and supervised by NS, TS, and HO. T. Nomura, HK, KO, and NS collected samples and clinical data, which were analyzed by T. Nomura, MK, and TN. All authors contributed to interpreting the data. The final manuscript was reviewed by all authors.

\section{Funding}

The authors received no funding for this study.

\section{Competing interests}

We declare no competing interests.

Correspondence and requests for materials should be addressed to T. Nomura.

\section{References}

1. Centers for Disease Control and Prevention. Interim clinical guidance for management of patients with confirmed coronavirus disease (COVID-19). Available at:

https://www.cdc.gov/coronavirus/2019-ncov/hcp/clinical-guidance-management-patients.html. Accessed 21 February 2021.

2. Wolfel, R. et al. Virological assessment of hospitalized patients with COVID-2019. Nature. 581, 465$46(2020)$.

3. La Scola, B. et al. Viral RNA load as determined by cell culture as a management tool for discharge of SARS-CoV-2 patients from infectious disease wards. Eur J Clin Microbiol Infect Dis. 39, 1059-1061 (2020).

4. Bullard, J. et al. Predicting infectious SARS-CoV-2 from diagnostic samples. Clin Infect Dis. 71, 26632666 (2020).

5. Centers for Disease Control and Prevention. Duration of isolation and precautions for adults with COVID-19. Available at: https://www.cdc.gov/coronavirus/2019-ncov/hcp/duration-isolation.html. Accessed 21 February 2021. 
6. European Centre for Disease Prevention and Control. Guidance for discharge and ending of isolation of people with COVID-19. Available at: https://www.ecdc.europa.eu/en/publications-data/guidancedischarge-and-ending-isolation-people-covid-19. Accessed 21 February 2021.

7. van Kampen, J. J. A. et al. Duration and key determinants of infectious virus shedding in hospitalized patients with coronavirus disease-2019 (COVID-19). Nat Commun. 12, 267 (2021).

8. Avanzato, A. et al. Case Study: Prolonged infectious SARS-CoV-2 shedding from an asymptomatic immunocompromised individual with cancer. Cell. 183, 1901-1912 (2020).

9. Centers for Disease Control and Prevention. People with certain medical conditions. Available at: https://www.cdc.gov/coronavirus/2019-ncov/need-extra-precautions/people-with-medicalconditions.html?CDC_AA_refVal=https\%3A\%2F\%2Fwww.cdc.gov\%2Fcoronavirus\%2F2019ncov\%2Fneed-extra-precautions\%2Fgroups-at-higher-risk.html. Accessed 21 February 2021.

10. Kitagawa, $\mathrm{H}$. et al. Effectiveness of 222-nm ultraviolet light on disinfecting SARS-CoV-2 surface contamination. Am J Infect Control. 49, 299-301 (2020).

11. An, J. et al. Clinical characteristics of the recovered COVID-19 patients with re-detectable positive RNA test. MedRxiv. 8, 1084 (2020).

12. Zhou, B., She, J., Wang, Y., Ma, X. The duration of viral shedding of discharged patients with severe COVID-19. Clin Infect Dis. 71, 2240-2242 (2020).

13. Gianfrancesco, M. et al. Characteristics associated with hospitalisation for COVID-19 in people with rheumatic disease: data from the COVID-19 Global Rheumatology Alliance physician-reported registry. Ann Rheum Dis. 79, 859-866 (2020).

14. Hsu, C. M. et al. COVID-19 infection among US dialysis patients: Risk factors and outcomes from a national dialysis provider. Am J Kidney Dis [Preprint]. Jan 17, 2021 [cited 2021 March 29]. Available from: https://doi.org/10.1053/j.ajkd.2021.01.003.

15. Ogando, N. S. et al. SARS-coronavirus-2 replication in Vero E6 cells: replication kinetics, rapid adaptation and cytopathology. J Gen Virol. 101, 925-940 (2020).

16. Matsuyama, S. et al. Enhanced isolation of SARS-CoV-2 by TMPRSS2- expressing cells. Proc Natl Acad Sci U S A. 117, 7001-7003 (2020).

\section{Figures}




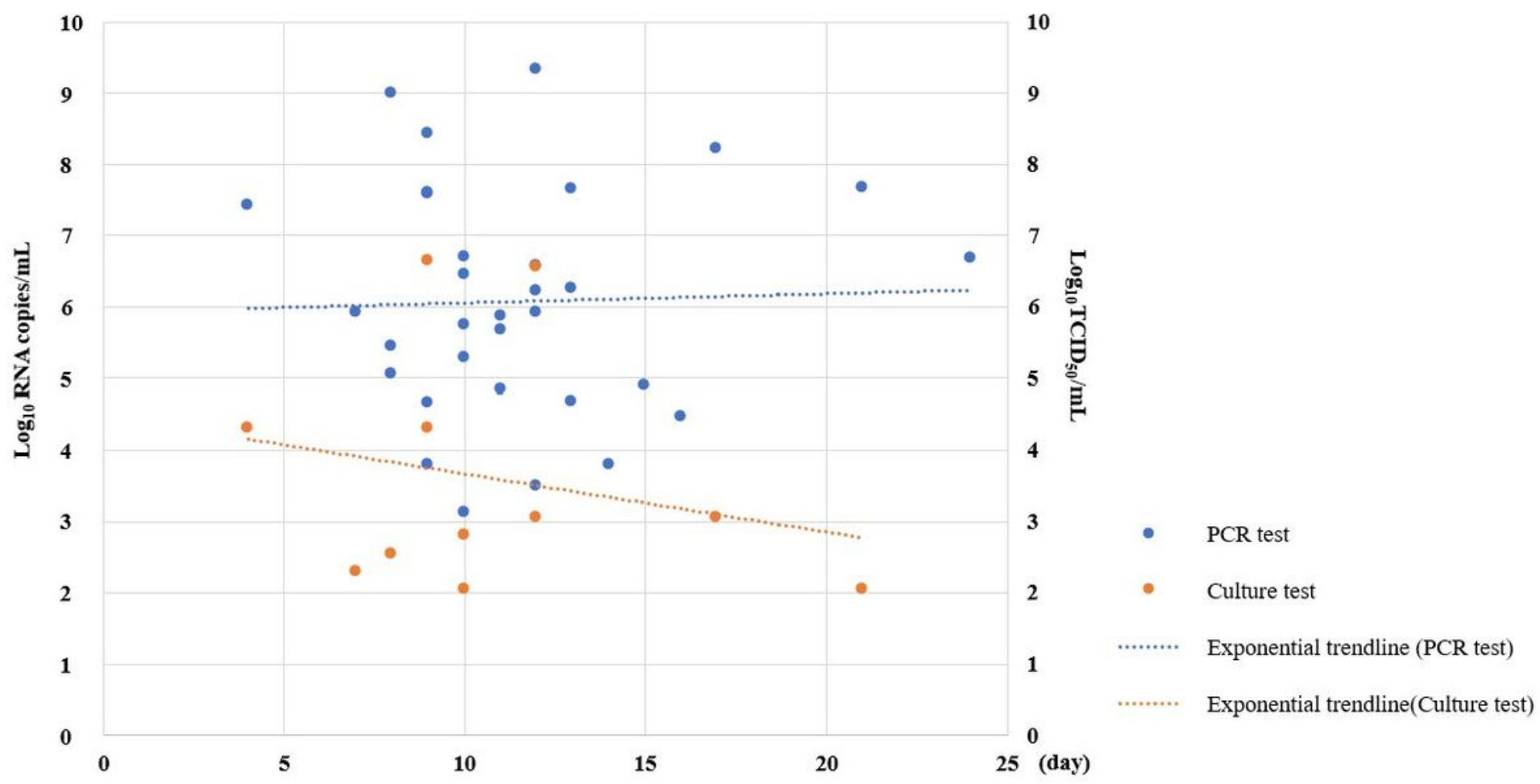

Figure 1

Quantitative results by type of test $(\mathrm{N}=33) \mathrm{PCR}$, polymerase chain reaction
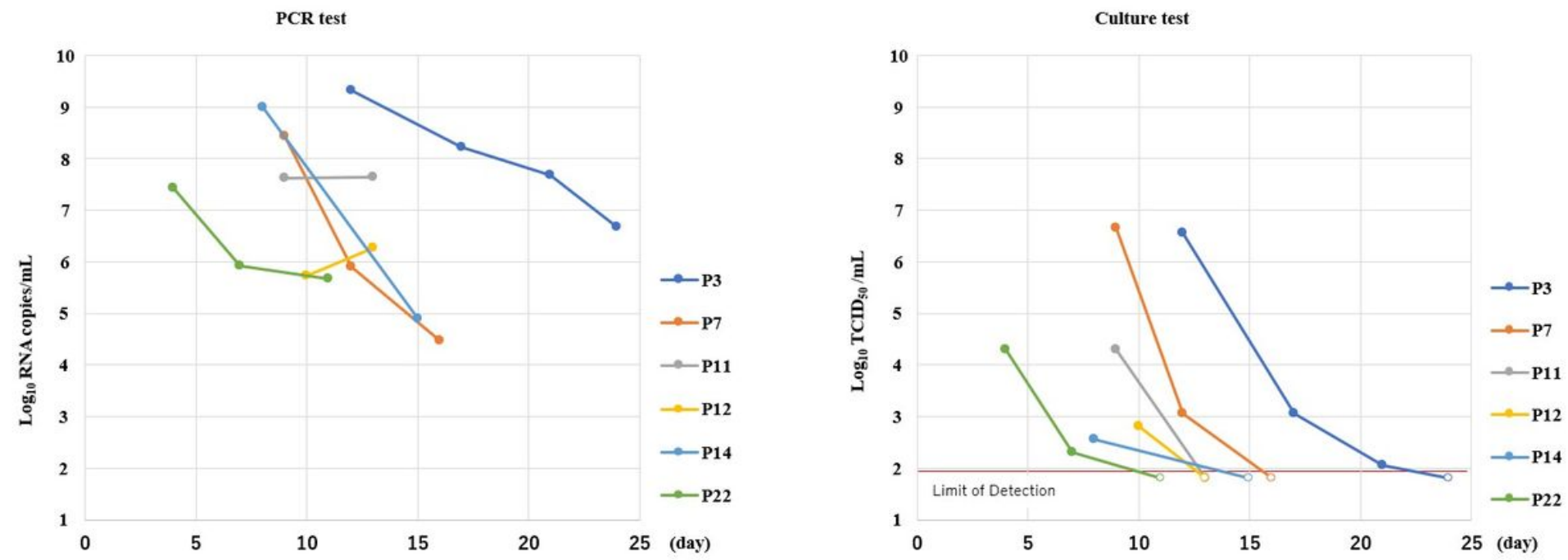

Figure 2

Time-course of conversion in patients with positive culture test and in patients with positive RT-qPCR test RT-qPCR, reverse transcriptase-quantitative polymerase chain reaction 